\title{
Pseudo-realia in the Romanian Translations of Various Hungarian Institutions and in the Hungarian Translations of Romanian Public Administration Terms ${ }^{1}$
}

\author{
Andras ZOPUS \\ University of Nyíregyháza (Hungary) \\ Institution of Linguistics and Literature \\ drsza@yahoo.com
}

\begin{abstract}
My presentation addresses an issue translators of RomanianHungarian legal and economic texts encounter almost day by day. Each field of translation is special in its kind, but translating legal/economic texts requires an especially accurate knowledge of the acts, laws, and concepts of both the source and target language since this is essential for the translated text to be really a quality, professional, and - last but not least - an intelligible one to the target-language audience, i.e. the customers.
\end{abstract}

Keywords: translation, bilingualism, diglossia, realia, Transylvania

In my work, I often need to check texts that contain concepts being either unintelligible or not appropriate to customers of Hungarian native language - it does not matter if they come from Hungary or Transylvania. Checking texts aims at the correction of technical terms in the text in addition to that of the grammatical mistakes. In many cases, Transylvanian translators classify a certain rate of the concepts of legal/public administration into the category of social-political sorts of realia. In such a way, they almost transform these into culture-dependent units, and they tend to use individual or peculiar concords instead of translating the concepts in question. These concords are, however, not correct in terms of legal language and, what is more, they may sometimes cause problems in the interpretation of the law. My examples present especially the difficulties of translating Romanian public administration terms into Hungarian, but some of them describe the issue of translating the Hungarian names of institutions into Romanian as well.

Realia, in other words: lexical units without equivalents, have several definitions. The difference between them is mainly based on how strong or weak

1 The article was translated from Hungarian by Béla Lukács. 
the link is between a certain non-equivalent lexical unit and a certain culture. The common feature of most definitions is that realia, i.e. culture-specific words, have no equivalents in the target language. This statement, however, seems true on the surface only because it is proved by huge amounts of existing translations that translators have always found some kind of (more or less adequate) solution. When talking about two languages, we may observe some lack of lexis, which frequently originates from the unfamiliarity of the denoted object of the source culture (Mujzer-Varga 2012: 59). According to Florin, realia are words and combinations of words denoting objects and concepts that are characteristic of the way of life, culture, social and historical development of one nation and alien to another. Since they express local and/or historical features, they have no exact equivalents in other languages (Florin 1993: 123).

In Kinga Klaudy's definition, "denotative entities being uniquely typical of the culture of the source language, such as food, drinks, items of clothing, currencies, units of measurement, institutions, ranks, offices, and the names of all of these entities in general, are termed realia" (Klaudy 2007: 170).

Representing a new aspect in defining realia, Mujzer-Varga introduces the term realia lexeme. Consequently, "realia lexemes are each lingual utterance being typical of a certain community; bringing about similar associations amongst its members due to their nearly common background knowledge; realia lexemes have connotative meanings and emotional content" (Mujzer-Varga 2012: 59). Classifying realia helps us mainly in terms of analysing texts from the point of view of pragmatics. Nedergaard-Larsen's categorization is one of the most interesting of these categories (Nedergaard-Larsen 1993: 210-211), and it divides realia into four main categories: geography, history, society, and culture.

Table 1: Classification of realia (Nedergaard-Larsen 1993)

\begin{tabular}{lll}
\hline \multicolumn{2}{c}{ Extralinguistic culture-bound problem types } \\
\hline Geography, etc. & $\begin{array}{l}\text { Geography } \\
\text { Meteorology } \\
\text { Biology }\end{array}$ & $\begin{array}{l}\text { mountains, rivers } \\
\text { weather, climate } \\
\text { flora, fauna }\end{array}$ \\
\cline { 2 - 3 } Cultural Geography & $\begin{array}{l}\text { regions, towns } \\
\text { roads, streets, etc. }\end{array}$ \\
\hline History & monuments, castles, etc. \\
\hline Eociety & People & wars, revolutions, flag day (in the U.S.A.) \\
\hline & Industrial level (economy) & trade and industry, energy supply, etc. \\
\hline Social organization & $\begin{array}{l}\text { defence, judicial system, } \\
\text { police, prisons, } \\
\text { local and central authorities }\end{array}$ \\
& Politics & $\begin{array}{l}\text { state management, ministries, } \\
\text { electoral system, political parties, } \\
\text { politicians, political organizations }\end{array}$ \\
\hline
\end{tabular}




\begin{tabular}{ll}
\hline Social conditions & $\begin{array}{l}\text { groups, subcultures, } \\
\text { living conditions, problems }\end{array}$ \\
\hline Ways of life, customs & $\begin{array}{l}\text { housing, transport, food, meals, } \\
\text { clothing, articles for everyday use, } \\
\text { family relations }\end{array}$ \\
\hline Rulture & $\begin{array}{l}\text { churches, rituals, morals, } \\
\text { ministers, bishops, } \\
\text { religious holidays, saints }\end{array}$ \\
\hline Education & $\begin{array}{l}\text { schools, colleges, universities, } \\
\text { lines of education, exams }\end{array}$ \\
\hline Media & TV, radio, newspapers, magazines \\
\hline Culture, leisure activities & $\begin{array}{l}\text { museums, works of art, } \\
\text { literature, authors, } \\
\text { theatres, cinemas, actors, } \\
\text { musicians, idols, } \\
\text { restaurants, hotels, } \\
\text { nightclubs, cafés, } \\
\text { sports, athletes }\end{array}$ \\
&
\end{tabular}

The next three classifications have (approximately) the same major categories. Florin (1993) and Ramière (2004) distinguish between geographical, historical, social, and cultural realia, though Florin (1993) names the last two of these 'social-territorial' and 'ethnographic', respectively; moreover, Ramière (2004) and Grit (1997) both combine these two into one 'socio-cultural' category. These categories are all relatively straightforward: geographical realia are references to places and other elements of our surroundings, social realia refer to elements from society, and cultural realia refer to elements from cultural life. Grit (1997) adds three additional categories to his taxonomy: public institutional realia, which refer to elements in the public sector, private institutional realia, which refer to the private sector and units of measurement (e.g. inch). These are all very broad categories, but out of the four taxonomies only Nedergaard-Larsen identifies subcategories within these general categories (Smets 2000: 18).

Table 2. Schematic overview of the taxonomies

\begin{tabular}{llll}
\hline Nedergaard-Larsen (1993) & Florin (1993) & Grit (1997) & Ramière (2004) \\
\hline Geographical & Geographical & Geographical & Geographical \\
\hline $\begin{array}{l}\text { Geography, Meteorology, } \\
\text { Biology }\end{array}$ & Historical & Historical & Historical \\
\hline Historical & Social-Territorial & Social-Cultural & Social-cultural \\
\hline Buildings, Events, People & & Private institutional & \\
\hline Social & $\begin{array}{l}\text { Public institutional } \\
\begin{array}{l}\text { Economy, Social } \\
\text { Socianization, Politics, } \\
\text { Customs }\end{array}\end{array}$ & & \\
\hline
\end{tabular}




\begin{tabular}{llll}
\hline Nedergaard-Larsen (1993) & Florin (1993) & Grit (1997) & Ramière (2004) \\
\hline Cultural & Ethnographic & Socio-cultural & Socio-cultural \\
\hline $\begin{array}{l}\text { Religion, Education, } \\
\text { Media, Culture }\end{array}$ & & \\
\hline
\end{tabular}

Notwithstanding, regarding linguistic differences, we need to be careful not to confuse the field of realia with the field of terms. There is a fundamental difference between realia and terms. Terms are the basis of scientific lexicon; their scope is a specialized, scientific literature; in other spheres, above all in artistic literature, they are used with a definite stylistic aim. It is not artistic literature where we can mainly come upon realia as they represent elements of local and historical features; we find them in some descriptive sciences also, but they are now used, above all, as denominations of described objects or even as pure terms.

Choosing the best of the possibilities available for conveying the message of a realia depends on several factors: the genre/nature of the text, the role of the realia in the text, the nature of the realia, the source and target language, and the reader's background knowledge of the realia. When it comes to various sorts of realia, a translator's dilemma is always whether to choose transcription or translation. It is the translator who has to make a decision, taking all the circumstances into consideration. The number of strategies for translating realia is limited, compared with the possibilities of classifying them into categories. Most of the theoretical solutions, however, are not always or barely feasible in practice; therefore, various expedient strategies are to be used in the course of translation.

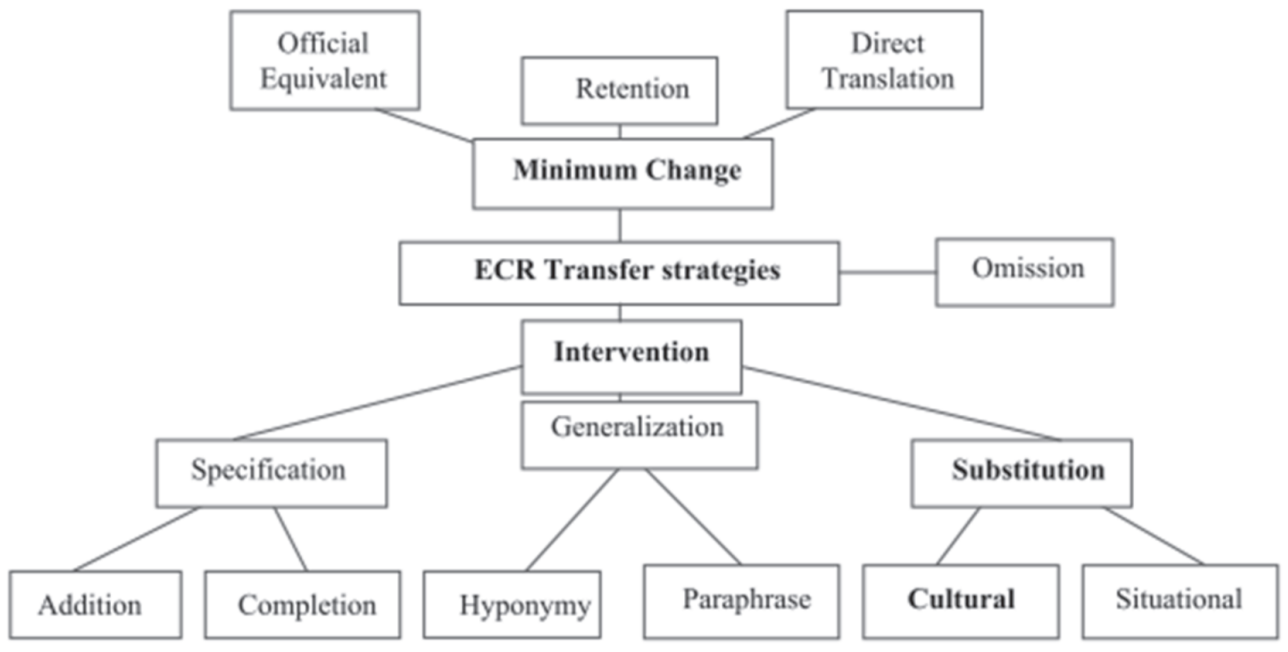

Figure 1. Taxonomy of subtitling strategies (Pedersen 2007: 31) 
Regarding the translations I have examined and the examples below, we cannot really have any sorts of realia in their proper sense; although one may find lexical examples standing without equivalents, many times, one can translate without any sorts of realia, provided the translator knows the legal background.

(1) Kormányhivatal (HU) ('Government Office’)

a. Instituție guvernamentală

'Government institution'

b. Oficiu guvernamental

'Government Office'

c. Departament guvernamental autorizat

'Authorized governmental department'

d. Agenție guvernamentală

'Governmental local office'

e. Birou Guvernamental

'Governmental office'

Frequently, the translation of the expression into Romanian is incorrect even in EU translations, which may be regarded the official ones. 'Agenție' occurs many times, but this word is misleading for Romanian readers because it belongs mainly to the conceptual class of 'képviselet' ('representation'), 'kirendeltség' ('local office'). In Hungary and before 2011, the government office had been a central administrative body created by law and operating with the Government's direction, ${ }^{2}$ and as from 1 January 2011 metropolitan and county government offices were established as the Government's regional administrative bodies with general competence. ${ }^{3}$ The heads of these are appointed by the prime minister and they manage these bodies under ministerial direction. Examining the position and role of this term, it is clear that the correct translation of 'kormányhivatal' ('government office') is 'oficiu guvernamental'.

(2) (Nyíregyházi) Fớiskola (HU) ('College of Nyíregyháza’)

a. Institutul de Învățământ Superior din Nyíregyháza 'Institution of Higher Education in Nyíregyháza'

b. Şcoala Superioară din Nyíregyháza 'School of Higher Grade in Nyíregyháza'

c. Institutul Postliceal din Nyíregyháza 'Post-Teacher Training Institution in Nyíregyháza'

d. Colegiul Universitar din Nyíregyháza 'Academic Students' Hostel in Nyíregyháza'

2 http://net.jogtar.hu/jr/gen/hjegy_doc.cgi?docid=a1000043.tv\#lbj15ideeb8

3 http://net.jogtar.hu/jr/gen/hjegy_doc.cgi?docid=A1000126.TV 


\title{
e. Colegiul din Nyíregyháza \\ 'Students' Hostel in Nyíregyháza'
}

A college is an institution in the Hungarian higher educational system, wherefore the two latter ones of the above possibilities are the most acceptable, paying special attention to their usage in several contexts. Then again, 'colegiu' in a Romanian context may be misleading as well because 'colegiu tehnic' is an institution in secondary education ('technical secondary vocational school'). While translating the names of similar Romanian/Moldavian institutions into Hungarian, we must pay special attention because the denotation of 'kollégium' in standard Hungarian is mainly 'diákotthon' ('students' hostel'), sometimes 'szakmai kollégium' ('college for advanced studies'), and not an institution in higher education.

\author{
Diplomă de bacalaureat (RO) ('Secondary School-Leaving Certificate') \\ a. Érettségi diploma \\ 'Degree Certificate of School-Leaving Examination' \\ b. Érettségi oklevél \\ 'Certificate of School-Leaving Examination' \\ c. Érettségi bizonyítvány \\ 'Secondary School-Leaving Certificate'
}

Despite the fact that official documents issued in Hungary are clearly nominated as ‘Érettségi bizonyítvány’ ('Secondary School-Leaving Certificate'), I have often encountered 'érettségi diploma/oklevél' ('Degree Certificate of SchoolLeaving Examination', 'Certificate of School-Leaving Examination') as well. We might simply consider the translator's negligence, but a diploma ('degree certificate') has a higher position in the translators' scale of values beyond the borders than 'bizonyítvány' ('certificate') has. Certificate is rather associated with schoolchildren's 'ellenőrző' ('mark-books'). This type of translation (érettségi diploma/érettségi oklevél - 'Degree Certificate of School-Leaving Examination', 'Certificate of School-Leaving Examination', 'Secondary SchoolLeaving Certificate') may be regarded as the communicative equivalent of the source-language text because it complies with the requirements of referential, contextual, and functional equivalence as well.

(4) Consiliu local/județean (RO) ('Local/county authority')
a. Helyi/városi/községi tanács 'Local/town/municipal council'
b. Helyi/megyei önkormányzat 'Local/county authority' 
Although the translation of 'consiliu' is almost self-evident, it is often translated as 'önkormányzat' ('local authority') too. In practice, local authority in Hungary

[...] means that the community in question is managed independently and entitled to make its own decisions regarding its own issues. In the case of a local government, in addition to the above facts, the sphere of authority of the government is simply to supervise local governments. Public affairs of a locality may be transferred to the competence and scope of duties of another organization through legal rules and in exceptional cases only. [...] Law enables local residents to discuss any questions with their local authority or to express their opinion through referenda. ${ }^{4}$

Local referenda and this sort of rights to make decisions are missing in local communities in Romania.

(5) Persoană fizică autorizată (RO) ('Individual with VAT number')

a. Vállalkozói engedéllyel rendelkező magánszemély

'Individual with entrepreneur's licence'

b. Adószámmal rendelkező magánszemély

'Individual with VAT number'

c. Engedéllyel rendelkező magánszemély

'Individual with a licence'

d. Önálló vállalkozás

'Independent business'

This concept always triggers lively debates on translators' deliberations and conferences. In my opinion, one may accept the second one only because in Hungary there is no such category as 'engedéllyel rendelkezô magánszemély' ('individual with a licence'); the sort of licence should be specified right at the beginning (forwarding licence/licence for tertiary education/licence for managing accommodation?). The translations in which we can read 'vállalkozó' ('entrepreneur'), 'vállalkozás' ('business') refer to 'egyéni vállalkozó' ('private entrepreneur'), which is a separate management category determined by Act CXV of 2009 on private entrepreneurs and private companies. ${ }^{5}$

(6) Cod unic de înregistrare (fiscală) (RO) ('VAT number')

a. Egyedi azonosító kód

'Unique identification code'

4 http://www.kormany.hu/hu/mo/onkormanyzatisag-magyarorszagon

5 http://net.jogtar.hu/jr/gen/hjegy_doc.cgi?docid=A0900115.TV\&celpara=\#xcelparam 
b. Egyedi regisztrációs szám

'Unique registration number'

c. Cégjegyzékszám

'Company registry number'

d. Adószám

'VAT number'

We can find the above expression in certificates of incorporation, registrations of companies, tax returns, and other relevant official documents. I encounter the mistranslation of that expression almost every day. In addition to the incorrect verbatim translations (a, b), 'cégjegyzékszám' ('company registry number') is not correct either because we have been talking about 'adószám' ('VAT number'). VAT number was termed and abbreviated in these forms (CUI) until 1 January 2000, under Act 359 of 2004. Its new term (codul de înregistrare fiscală, CIF) has been used since 1 July $2007 .^{6}$

(7) Certificat constatator ( $R O$ ) ('Certificate of Incorporation')

a. Megállapító igazolás

'Establishing Certificate'

b. Cégnyilvántartási igazolás

'Certificate for Registering the Company'

c. Cégmúködési bizonylat

'Certificate for Company Capability'

d. Cégbíróság által kiállított Megállapító igazolás

'Establishing Certificate issued by Registry Court'

e. Cégbejegyzési hivatal által kibocsátott múködőképességi igazolvány 'Certificate for Company Capability issued by Registry Office'

f. Cégkivonat

'Certificate of Incorporation'

Not knowing the terms and documents related to the Registry Court in Hungary leads to quite a lot of problems about translating 'cégkivonat' ('Certificate of Incorporation'), a term that should be known to every (technical) translator. 'Megállapító igazolás' ('Establishing Certificate') is so simple that it has no meaning whatsoever; 'Cégbejegyzési hivatal által kibocsátott múködőképességi igazolvány’ ('Certificate for Company Capability issued by Registry Office') attempts to imply the profound knowledge of the terminology. Actually, neither translation is acceptable, while the latter one is also faulty because a certificate of incorporation will not verify the capability of a company. Unfortunately, translations like these and even stranger ones appear not only on paper, but on

6 https://ro.wikipedia.org/wiki/Cod_de_Identificare_Fiscal\%C4\%83 
the Internet, on websites as well (i.e. those of notary publics and law offices), which we may deem authentic and valid.

(8) Pedeapsă cu închisoarea (RO) ('Sentenced to deprivation of liberty')
a. Börtönbüntetés
'Imprisonment'
b. Szabadságelvonás
'Deprivation of liberty'
c. Szabadságvesztés-büntetés
'Sentenced to deprivation of liberty'

Here, I point out a common pitfall of translating judgement sentences passed in Romania. In Hungary, legal rules provide two forms of imprisonment: it may take a specific period or for life. Enforcement may be ordered in three grades depending on the seriousness of the crime: maximum-security prison, mediumsecurity prison, or minimum-security prison. The governing law pertaining to certain grades is stipulated in Act CCXL of 2013 on Law Enforcement and Measures. ${ }^{7}$ The court determines the grade of law enforcement in its sentence. In Romania, there are no grades similar to the ones in Hungary in enforcing imprisonment. Accordingly, 'börtönbüntetés' ('imprisonment') is used almost automatically and in most cases it is only one of the possible translations, and, if used in its general sense, it will not reflect the grade of the passed penalty.

\section{Conclusions}

Summing up the above-mentioned discussions, exchanges of letters, and various opinions voiced on conferences, we may state that considering technical terms as sorts of realia brings about a complex problem, and the roots of rejecting a technical term (which is clear many times) consist of a lot of factors. I emphasize the following:

The bilingualism of the translators from the Hungarian communities living in diaspora: bilingualism is typical of ethnic groups in minority, and this applies to the Hungarian communities living in diaspora. They usually speak a language to communicate with their families, relatives, in everyday life and personal relations, while the other one is used in offices, schools, and public life only. If the levels of the knowledge of these two languages are not equal, the dominant language will interfere with the other one: this appears in its grammatical system and translations, too. While analysing the definitions of bilingualism and diglossia, we may state that the Transylvanian translators' situation is clear from

7 http://net.jogtar.hu/jr/gen/hjegy_doc.cgi?docid=A1300240.TV 
the point of view of bilingualism because criteria in broader and narrower senses are met, e.g.: both Hungarian and Romanian are mastered as mother languages (Bloomfield 1933), translators have one of the four basic communicative skills (speaking, listening comprehension, writing, reading) in the second language (in this case: Romanian) in addition to the first one (MacNamara 1967), they are able to communicate in at least two languages in a mono- or multilingual community, and they are able to identify themselves or sympathize with both (or all) groups of languages and cultures partly or completely (Skutnabb-Kangas 1984).

Translators' diglossia: they use two variants of Hungarian, the dialect and standard form, but we may talk about regional standard language in the case of standard language. Obviously, regional standard language takes place between standard language and a dialect: it is a variation which has some colouring in terms of dialect units, e.g. softer pronunciation of dialects and, occasionally, words of dialects. The extent of this influence is not disturbing from the perspective of standard language. In order to justify that there is diglossia in some sense amongst the given Transylvanian translators, we need to talk about a regional standard language which has evolved at the boundaries of dialects. This regional standard language is a variation of the standard language, the first one having evolved through dialectal interactions; moreover, its place is between dialects and the standard language in terms of its relationship to norms. When writing, its users employ the literary variant, while their utterances are prevailed by standard language norms, but one can observe the traits of surrounding dialects, depending to various extents on locality and time. The fact that regional standard language, as a phenomenon of contacts, has appeared may be interpreted not only as the expansion of standard language towards regionalism but also as the spot of intrusion of regionalism into standard language. According to the model of variability, under the influence of standard language, the rules of competence of dialects are added to those rules of the standard language in such a way that those which are typical to dialects remain. In addition, we may say that a new regional substandard is taking shape as a consequence of three tendencies: (1) dialects are pushed back, (2) they are becoming variable and destandardizing, and (3) that they are losing their diglossic features. "Obviously, losing diglossic features may take place only amongst diglossic speakers (dialectal + regional standard lingual, dialectal + standard lingual, regional standard lingual + standard lingual), resulting in giving up the dialect or regional standard language" (Kiss 2013: 88). Summing up, translations have units being intelligible to speakers of regional standard language but inaccurate with a view to translations for special purposes. Completely avoiding such units is possible only if translators give up their rigid points of view of regional standard language - which may easily lead to mistakes in translation for special purposes. 


\section{References}

Bloomfield, Leonard. 1933. Language. New York: Holt, Rinehart \& Winston.

Florin, Sider. 1993. Realia in translation. In: Zlateva, Palma (ed.), Translation as social action. Russian and Bulgarian perspectives, 122-128. London: Routledge.

Grit, Diederik. 1997. De Vertaling Van Realia. Filter 4: 42-48.

Kiss, Jenő. 2013. A regionális nyelvhasználat és a nyelvi kontaktusok. Problémavázlat [The use of regional language and language contacts. A draft]. Nyelvelmélet és Kontaktológia 2: 80-94.

Klaudy, Kinga. 2007. Nyelv és fordítás [Language and translation]. Budapest: Tinta Könyvkiadó.

Macnamara, John. 1967. The bilingual's linguistic performance. Journal of Social Issues 23: 58-77.

Mujzer-Varga, Krisztina. 2012. Reáliák fordítása irodalmi szövegekben [The translation of realia in literary texts]. In: Júlia Dróth (ed.), Tanulmányok a szakfordítás és a fordítóképzés aktuális témáiról [Studies on the present-day issues of technical translation and interpreter training), 58-68. Gödöllő: Szent István Egyetem - Nyelvi Központ.

Nedergaard-Larsen, Birgit. 1993. Culture-bound problems in subtitling. Perspectives: studies in translatology 1(2): 207-240.

Pedersen, Jan. 2007. Cultural interchangeability: the effects of substituting cultural references in subtitling. Perspectives: studies in translatology 15(1): 30-48.

Ramière, Nathalie. 2004. Comment le sous-titrage et le doublage peuvent modifier la perception d'un film: analyse contrastive des versions sous-titrées et doublées en français du film d'Elia Kazan, 'A Streetcar Named Desire' (1951). Meta 49 (1): 102-114.

Skutnabb-Kangas, Tove. 1984. Bilingualism or not. The education of minorities. Clevedon: Multilingual Matters LTD.

Smets, Lieselotte. 2000. Transferring British culture in Dutch subtitles: The translation of realia in 'Yes, Minister'. Lessius: Antwerpen. Unpublished MA thesis. http://docplayer.net/3161660-Toegepaste-taalkunde-transferringbritish-culture-in-dutch-subtitles-the-translation-of-realia-in-yes-minister. html. 